\title{
The impact of brand value on brand selection: Case study of mobile phone selection
}

\author{
Nasr Azad $^{\mathrm{a}^{*}}$ and Maryam Safaei ${ }^{\mathrm{b}}$
}

${ }^{a}$ Department of Management, Islamic Azad University, South Tehran Branch, Tehran, Iran ${ }^{b}$ Department of Management, Payame Noor University, Tehran, Iran

\begin{tabular}{l}
\hline A R T I C L E I N F O \\
\hline Article history: \\
Received October 1, 2011 \\
Received in Revised form \\
November, 14, 2011 \\
Accepted 15 February 2012 \\
Available online \\
27 February 2012 \\
\hline Keywords: \\
Perception quality \\
Word of mouth advertisement \\
Brand image \\
Mobile industry
\end{tabular}

\section{A B S T R A C T}

\begin{abstract}
There are many evidences to believe that customers select their products based on brand name. Products also maintain their own characteristics, which make them differentiable from others. In this paper, we present an empirical study to determine important factors influencing customers' purchasing intend for cellular phones in capital city of Iran, Tehran. The proposed study of this paper designs a questionnaire consists of 16 questions and distribute them among 428 people. The results of the study show that there are some positive relationships between exclusive name and quality perception, between exclusive name and word of mouth advertisement, between quality perception and fidelity, between word of mouth advertisement and brand name and between brand name image and brand name.
\end{abstract}

(c) 2012 Growing Science Ltd. All rights reserved.

\section{Introduction}

Brand is one of the most important intangible assets in today's enterprises and in many cases; an enterprise is mostly valued mainly based on its brand. During the past few two decades, there have been numerous efforts to measure the impact of brand on customer's purchasing intention.

Yoo and Donthu (2001) presented a model for developing and validating a multidimensional consumer-based brand equity scale. Baldauf et al. (2009) explains that despite the fact that both product-country images (PCI) and firm assets such as brand equity have been studied in different contexts, There is only limited number of research works on the combined performance effects of these two components (Bendixen et al., 2004; Boo et al., 2009). There are extensive studies dedicated on brand equity primarily from a consumer viewpoint, but there are not much work on retailer's point of view. Retailers are the actual participants in the value chain who sell their products to consumers and they are able to impact consumers' evaluations and buying decisions, substantially. Baldauf et al.

\footnotetext{
* Corresponding author. Tel. + 982122895719

E-mail addresses: dr.naserazad@yahoo.com (N. Azad) 
(2009) investigated the effects of retailer-perceived brand equity and ultimate brand profitability performance and marketing activities on brand equity. They reported that both marketing activities and PCI influence retailer-perceived brand equity with PCI positively influencing brand profitability performance.

Bandyopadhyay and Martell (2007) offered a specific method to measure attitudinal loyalty. They used a survey data with a large sample of 1800 respondents, which incorporated both purchase patterns and attitudes of the respondents for all major brands of toothpaste, to show that behavioral loyalty could be influenced by attitudinal loyalty across various brands of the toothpaste group. They also explained that a third behavioral is also included along with two known behavioral patterns viz. single and multiple users since a non-user has the potential to become a consumer in future.

Burmann et al. (2009) developed a new integrated brand equity technique by exploring the sources of brand equity from both internal and external point of views at the behavioral and financial levels to reach a more comprehensive and sustainable brand equity measurement method.

Netemeyer et al. (2004) presented four studies, which developed measures of "core/primary" facets of customer-based brand equity (CBBE). The methods are based on CBBE frameworks and the figures chosen were perceived quality (PQ), perceived value for the cost (PVC), uniqueness, and people's attraction to pay a price premium for a brand. Their results recommended that PQ, PVC, and brand uniqueness are potential direct antecedents of the price premium payment for a brand.

Homburg et al. (2010) explain that in business-to-business (B2B) environments, many service providers concentrate their branding activities on the dissemination of their brand name and logo without working on brand identity. Therefore, the creation of brand awareness plays an important role in various B2B branding strategies. They investigated under which conditions brand awareness was associated with market performance in a B2B context. Their results from a cross-industry study of more than 300 B2B firms indicated that brand awareness influences market performance.

Joon-Wuk Kwun and Oh (2007) investigated on how consumers could make an assessment on lodging brand portfolios and demonstrated the important role of brand-specific associations and brand portfolio factors in forming brand behaviors toward extended brands. They recommended that brandspecific associations and brand portfolio influence consumers' evaluations of extended brands. Besides, brand fit and familiarity in their study were found to be important in consumers' behavior formation because they moderate behavior transferability between a brand portfolio and its extended brands.

Kim et al. (2008) introduced five factors, which impact the creation of brand equity through successful implementation of CRM including trust, customer satisfaction, relationship commitment, brand loyalty, and brand awareness. An empirical test of the relationships among these factors recommended that many hospitals could be successful in creating image and positive brand equity if they could manage their customer relationships well.

Kim and Hyun (2011) presented a model to investigate the impact of marketing-mix efforts and corporate image on brand equity in the IT software sector. Their results showed that all the marketing-mix efforts positively influence the overall value of brand equity, which is a proxy of market performance and corporate image mediates the effect of the marketing-mix efforts on the three dimensions of brand equity.

Lee and Back (2008) investigated CHRIE conference attendee behaviors from the perspective of brand equity using structural equation analyses and the results stated that professional education, staff service, site selection, and social networking were positively associated with brand satisfaction, whereas brand awareness was negatively related with it. Their findings also recommended substantial implications for practitioners and academics. 
Pappu and Quester (2006) presented an empirical study on consumer-based method for retailer equity measurement. They addressed some of the limitations related to current retailer equity measurement such as a lack of clarity regarding its nature and dimensionality and conceptualized retailer equity as a four-dimensional construct comprising retailer awareness, retailer associations, perceived retailer quality, and retailer loyalty. Kohli et al. (2005) performed a study of evaluation of new brand names and demonstrated that meaningful brand names continue to be evaluated more favorably than nonmeaningful names.

The brand names also impact evaluations of quality and other product attributes. Sweeney and Swait (2008) studied the effects of brand credibility on customer loyalty by investigating the relative importance of additional role of the brand in managing the churn of current customers of relational services and indicated that brand credibility serves in a defensive role and it substantially enhances word-of-mouth and reduces switching behaviors among customers. Huang and Sarigöllü (2011) investigated on how brand awareness is associated with market outcome, brand equity, and the marketing mix.

The study of this paper attempts to study the relationship between brand name and other product characteristics such as quality perception. The organization of this paper first presents details of survey in section 2. Section 3 explains the findings of the survey and concluding remarks are given in the last to summarize the contribution of this paper.

\section{Proposed study}

The proposed study of this paper uses a questionnaire consists of 16 questions and distributes it among 428 people who are randomly chosen from the people who live in Tehran, the capital city of Iran. Cronbach Alpha (1951) has been calculated as 0.9, which well above the minimum desirable level.

About $56.3 \%$ of the participants were female and the remaining $43.7 \%$ were man. In addition, $57.0 \%$ of the participants were single and the remaining $43.0 \%$ were married. $17.3 \%$ of the participants were 20 years or younger, $62.1 \%$ of the participants aged between 21 to 30 years, $12.6 \%$ between 31 to 40 , $5.6 \%$ were between 41 to 50 and only $2.3 \%$ were older than 50 . Table 1 shows people's educational background, income and brand name they use.

Table 1

Educational background, Income and brand name

\begin{tabular}{llllll}
\hline Years of education & $<12$ & 12 & 14 & 16 & $>16$ \\
Percentage & 7.5 & 14.5 & 9.3 & 50.9 & 17.8 \\
\hline Income & $<300$ US\$ & Between 300US\$ and 600US\$ & & $>600$ US\$ \\
Percentage & 53.7 & & 36.0 & & 10.3 \\
\hline Brand name & Nokia & Sony Erikson & Samsung & Others & \\
Percentage & 45.8 & 32.7 & 15.7 & 6.1 & \\
\hline
\end{tabular}

\section{Results}

In this section, we present details of the finding on the implementation of the proposed study. In our study, we have used LISREL software package to analyze the questions, which were gathered using Likert scale (Likert, 1932). Table 2 shows details of our finding along with the questions.

The results of LISREL are GFI $=0.90, \mathrm{AGFI}=0.91$, NFI $=0.89$, NNFI $=0.88$, which are well above the desirable value. Fig. 1 and Fig. 2 show details of our findings. In Fig. 1, pq represents perception quality, lo is fidelity, image represent the image of the mobile phone, wom represents word of mouth advertisement and finally be shows brand value, respectively. 
Table 2

Statistical results

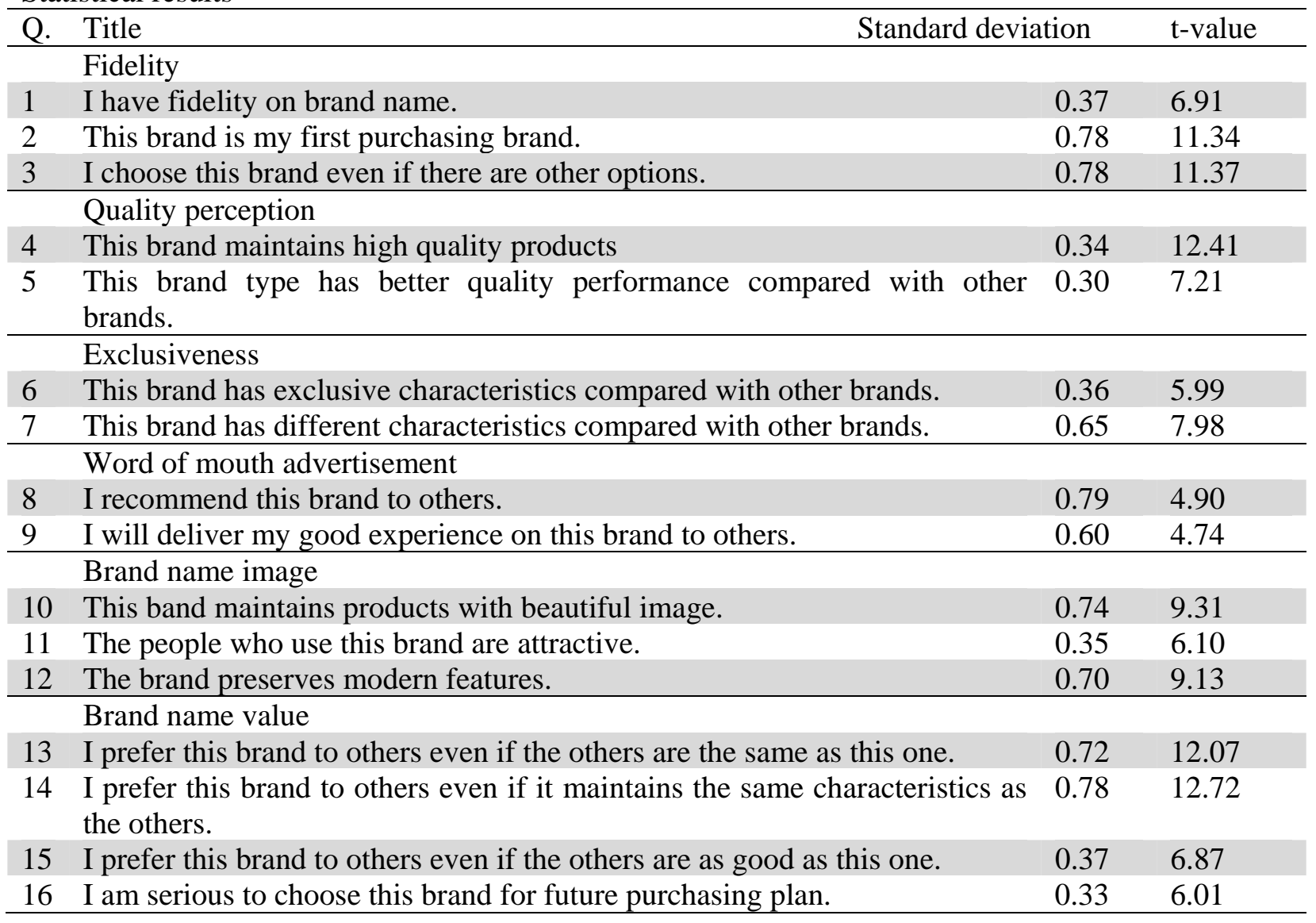

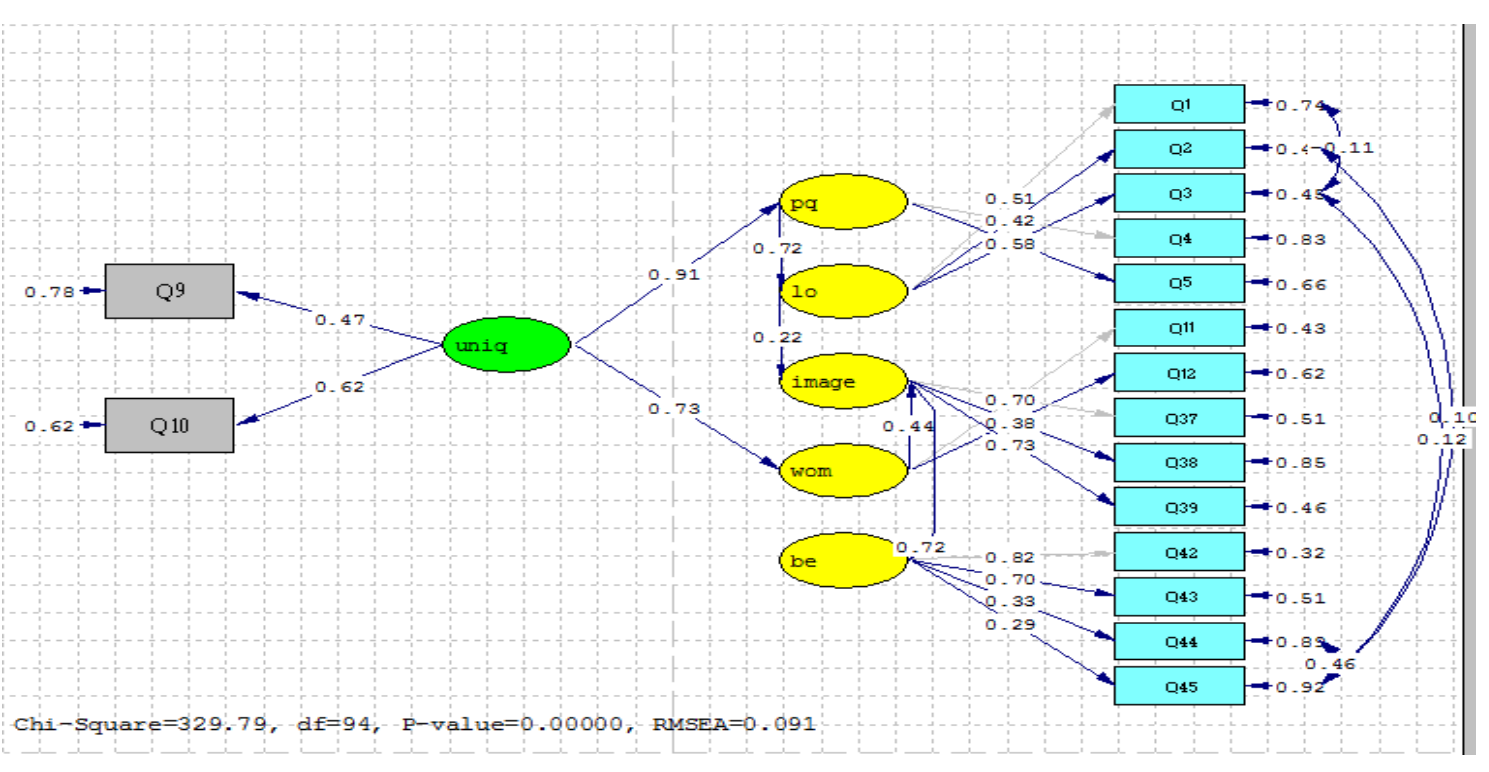

Fig. 1. Structural modeling framework 


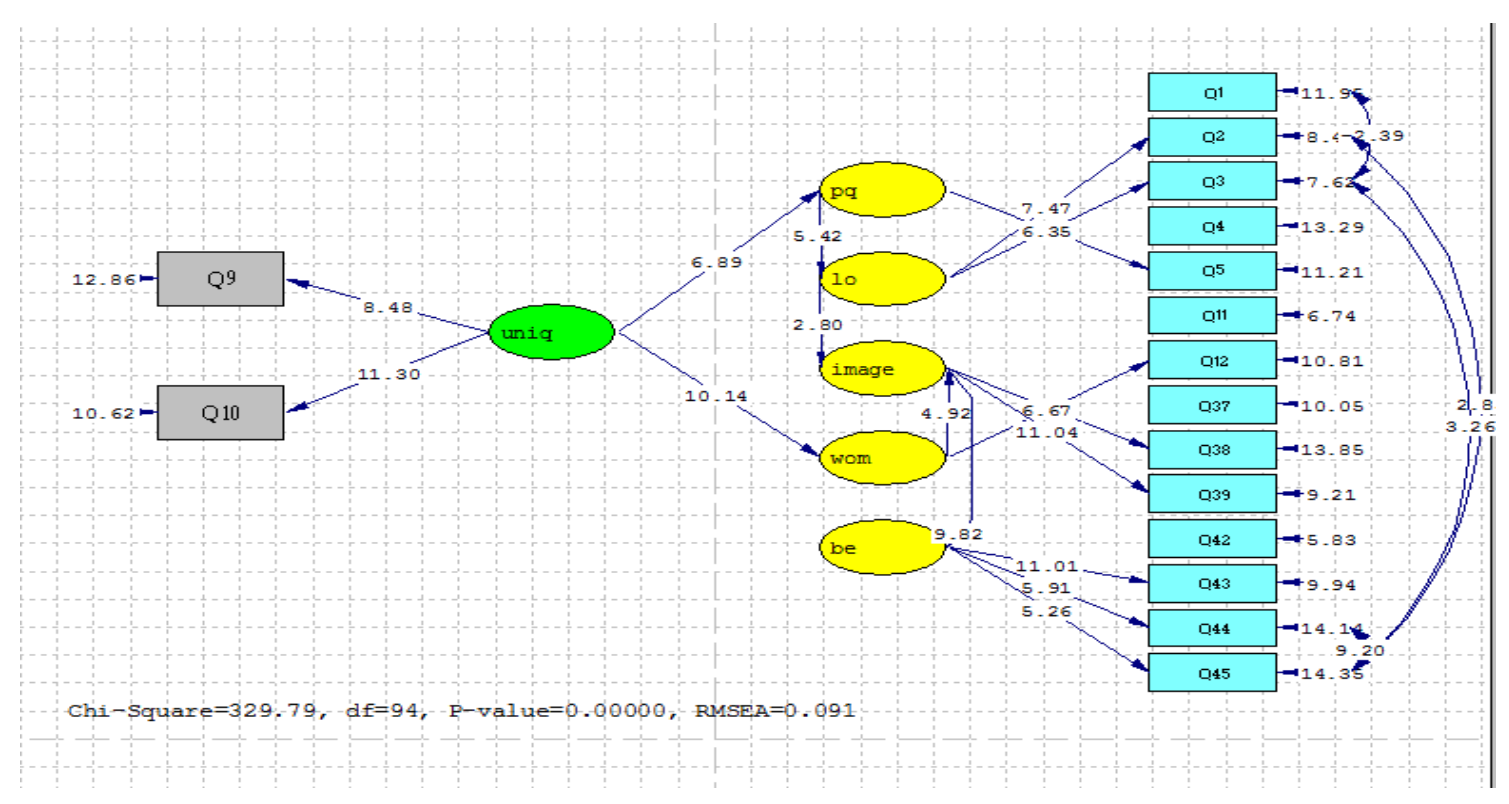

Fig. 2. Meaningful observations for structural equations

As we can observe the following relationships exists among all variables,

1. There is a positive and meaningful relationship between brand name and quality perception. Therefore, it seems that if a product is exclusive, high quality products will be considered.

2. There is a meaningful and positive relationship between brand name and word of mouth advertisement. Therefore, it seems that if a customer is interested in an exclusive product, he/she will choose based on positive words surrounding around.

3. There is a positive and meaningful relationship between fidelity and perception quality. In other words, customers will be faithful to high quality products.

4. There is a positive and meaningful relationship between brand image and word of mouth advertisement. In other words, the more customers hear from a brand name, the more they are interested in the name.

5. There is a positive and meaningful relationship between brand name image and the selection of a product. In other words, the more customers hear from a brand, the more customers choose that brand.

\section{Conclusion}

In this paper, we have presented an empirical study to determine important factors influencing customers' purchasing intend for cellular phones in capital city of Iran. The proposed study of this paper designed a questionnaire consists of 16 questions and distributed them among 428 people. The results of the study indicated that there are some positive relationships between exclusive name and quality perception, between exclusive name and word of mouth advertisement, between quality perception and fidelity, between word of mouth advertisement and brand name and between brand name image and brand name.

\section{Acknowledgment}

The authors would like to thank the people who participated in our survey and contribute their thoughts. 


\section{References}

Baldauf, A., Cravens, K. S., Diamantopoulos, A., Zeugner-Roth, K. P. (2009). The Impact of Product-Country Image and Marketing Efforts on Retailer-Perceived Brand Equity: An Empirical Analysis. Journal of Retailing, 85, 437-452.

Bandyopadhyay, S., \& Martell, M. (2007). Does attitudinal loyalty influence behavioral loyalty? A theoretical and empirical study. Journal of Retailing and Consumer Services, 14(1), 35-44.

Bendixen, M., Lalala, A., Bukasa., A., \& Russell, A. (2004). Brand equity in the business-to-business market. Industrial Marketing Management, 33, 371- 380.

Boo, S., Busser, J., \& Baloglu, S. (2009). A model of customer-based brand equity and its application to multiple destinations. Tourism Management ,30,219-231.

Burmann, C., Jost-Benz, \& M., Riley, N. (2009). Towards an identity-based brand equity model. Journal of Business Research, 62(3), 390-397.

Cronbach, L. J. (1951). Coefficient alpha and the internal structure of tests. Psychometrika, 16(3), 297-334.

Homburg, C., Klarmann, M. , \& Schmitt, J. (2010). Brand awareness in business markets: When is it related to firm performance?. International Journal of Research in Marketing, 27,201-212 .

Huang, R., \& Sarigöllü, E. (2011). How brand awareness relates to market outcome, brand equity, and the marketing mix. Journal of Business Research, 65(1), 92-99.

Joon-Wuk Kwun, D., Oh, H. (2007). Consumers' evaluation of brand portfolios. Hospitality Management ,26, 81-97.

Kim, K.H., Kim, K.S., Kimc, D.Y., Kimd, J.H., \& Kange, S.H. (2008). Brand equity in hospital marketing. Journal of Business Research, 61, 75-82.

Kohli, C.S., Harich, K.R., \& Leuthesser, L. (2005). Creating brand identity: a study of evaluation of new brand names. Journal of Business Research, 58, 1506- 1515.

Kim, J.H., \& Hyun, J. Y. (2011). A model to investigate the influence of marketing-mix efforts and corporate image on brand equity in the IT software sector. Industrial Marketing Management, 40, 424-438.

Lee, J.S., Back, K.J. (2008). Attendee-based brand equity. Tourism Management, 29, 331-344.

Likert, R. (1932). A Technique for the Measurement of Attitudes. Archives of Psychology, 140, 1-55.

Netemeyer, R.G., Krishnan, B., Pullig, C., Wang, G., Yagci, M., Dean, D., Ricks, J., Wirth, F. (2004). Developing and validating measures of facets of customer-based brand equity. Journal of Business Research, 57, 209- 224.

Pappu, R., Quester, P. (2006). A consumer-based method for retailer equity measurement: Results of an empirical study. Journal of Retailing and Consumer Services ,13, 317-329.

Sweeney, J., \& Swait, J. (2008). The effects of brand credibility on customer loyalty. Journal of Retailing and Consumer Services, 15, 179-193.

Yoo, B., \& Donthu, N. (2001). Developing and validating a multidimensional consumer-based brand equity scale. Journal of Business Research, 52, 1-14. 